\title{
Development Of Learning Video To Boost Grade IV Students Citizenship Learning Outcomes
}

\author{
Ulfah Nur Hikmah, Farid Ahmadi \\ Department of Elementary School Teacher Education, Faculty of Education, Semarang State University, \\ Semarang, Indonesia \\ Corresponding email: ulfahnurhikmah57@gmail.com
}

\begin{abstract}
This study aims to determine the development, feasibility, and effectiveness of video media globalization of learning material in the subjects of Civics $4^{\text {th }}$ grade SDN 01 Purwoyoso Semarang. This research is a development (Research and Devlopment). The development model used is the Waterfall model. The population in this study are students of SDN 01 Purwoyoso totaled 27 students. Data collection techniques are test and non test. The development consists of five stages: analysis, design, implementation, testing, and maintenance. Results of the assessment of the material validator figures show the percentage of $82.14 \%$ to the category of "Eligible". As for the assessment of media validator figures show the percentage of $85 \%$ to the category of "Very Decent". Based on the results obtained by the Sig t test (two-tailed) of 0.000.Value Sig (2tailed) of $0.000<0.05$. It can be concluded that Ho is rejected and Ha accepted, which means there are significant differences between the learning outcomes of globalization Civics material before and after using the instructional video media. Thus instructional video media products is feasible and effective for use in the process of learning civics.
\end{abstract}

Keywords:civics; instructional video media; learning outcomes

\section{Introduction}

Everyone is entitled the appropriate education. The education can be taken through two tracks, i.e. formal and non-formal education. Through education, somebody is expected to be able to develop all his potentials so that he can be an individual person who is intelligent, skilled, and has good personality. Peraturan Menteri Pendidikan Nasional Nomor 22 Tahun 2006 (Regulation of Minister of Education: 22/2006) states that citizenship studies can facilitate the character building of the students. In fact, several problems were found in the learning process of citizenship studies in world of education.

The problems regarding the learning of Citizenship studies were found in grade IV of SDN Purwoyoso 01. Based on the unstructured interview with the classroom teacher, the conducted learning has some problems. Among them are that the learning conducted by the teacher was less attractive, the learning has been teacher-centered, and the teacher has not applied the information technology-based media to the learning. As stated by Kusatandi and Sutjipto (2013:8) teaching tool is the tool that can be helpful in the teaching and learning process and it functions to expound the meaning of the conveyed message so it can reach the learning objectives better and more perfectly. In Citizenship studies learning process, the teacher has been applying a teaching tool. She, however, has not used the ICT-based tool and she only used the textbooks or workbook as the tools.

Rifa'I and Anni (2012:69) stated that the learning outcomes were the attitude transformation occuring to the students after experiencing the learning activities. The acquisition of the attitude transformation aspects depends on what they have learnt. The student less enthusiasm for engaging in the learning influenced their final exam marks of Citizenship subject in odd semester of 2015/2016 school year. They still got poor grade point for Citizenship final exam. This was shown by average Citizenship final exam grade point of grade IV students of SDN Puwoyoso 01 which did not meet the mastery learning criteria (KKM), i.e. 63; of 27 students, 17 63\%) got the grade point meeting KKM, while 10 (37\%) got below-KKM grade point.

I also conducted mini-research aiming to find the what kind of media was needed by the teacher and the students. The mini research shows that the teacher and the students need attractive ICT-based media such as video, thus it can boost Citizenship learning outcome. As stated by Kusatandi and Sutjipto (2013:8), the learning media is a tool that is helpful for the learning process and it functions to expound the conveyed message, so it can reach the learning objectives better and more perfectly. The application of the teaching tool in the learning process must be suitable with the taught lesson. 
Various kinds of interactive learning $b$ media can support the teaching and learning process. One of them is learning video. Daryanto (2013:88) stated that video was everything that enables audio signal to be combined with motion pictures in sequence. Video can be used in the learning because it $\mathrm{c}$ gives the students unexpected experiences. In addition, video is combinable with animation and speed setting to demonstrate its changes from time to time.

Based on the description above, I got interested in conducting research and development titled Pengembangan Media Video d. Pembelajaran Globalisasi untuk Meningkatkan Hasil Belajar Pkn (Studi Kasus: Siswa Kelas IV SDN Purwoyoso 01 Semarang) (Development of Video on Globalization as Learning Media to Improve Citizenship Learning Outcomes [Case Study: Grade IV Students of SDN Purwoyoso 01 Semarang).

\section{Research Method}

Research and Development is a research method applied to create certain product and to test the effectiveness of the product (Sugiyono 2015:407). This study used Waterfall model. Basil (2012:vol.2) said that the model is the classic one that systematically and sequentially build a software. Meanwhile, the procedure of the research was adopted from 5 Waterfall research phases, i.e. analysis, design, implementation, testing, and maintenance. The research subjects are 27 grade IV students of SDN Purwoyoso 01 Semarang. This study used saturated sampling as sampling method. The data were collected through interviews, questionnaire, documentation, and testing. The study used quantitative descriptive method as data analysis method.

\section{Results And Discussion}

The followings are measures that I took for in terms of developing the learning video.

a. The first phase is analysis. Based on the problems and the analyzed questionnaire on needs, I decided to choose Citizenship subject. I determined SK, KD, dan indicators based on the syllabus. The lesson that I chose to make the learning video was Globalization.
The second phase was design. In this phase, I made the design (storyboard) to ease myself to make the learning video. I also determine the role that would be played in the video. In addition, I determined the software used to process the video.

The third phase was implementation. I practiced the making process for the learning video. There were 3 figures for the video, i.e. two grade two male students and an adult woman. My roles were a narrator and a voice actor in the video. I used Proshow Producer, Adobe Premiere Pro, dan Cyberlink for video processing.

. The fourth phase was testing. The processed learning video was then proposed to lesson material and media validators. The validators then gave feedbacks on the learning video, then I made revision on it. After making revision, I conducted small group testing on 4 students of SDN Purwoyoso 02 Semarang. I, subsequently, made large group testing in SDN Purwoyoso 01 Semarang.

e. The fifth phase was maintenance. I did not practice this phase as I merely tested it.

\section{Validity Testing of Learning Video Feasibility}

The instructor who assess the validity of the Citizenship lesson material was Harmanto, M.Pd. The assessment aspects in the validity testing were materials suitability, comprehensibility, sequence, language, and completeness. The average percentage of the testing validity was $82.14 \%$ that meant "Good" or feasible. The validity testing shows that the lesson materials are proper to be tested, with revision.

The instructor who assess the video as media was Entot Suharto. Aspects of the testing were media display, text and picture layout, the volume of the voices and the music, and interaction. The average percentage of the testing was $85 \%$ that means "excellent". The validity testing shows that the learning video is excellently feasible to be tested, with revision.

\section{Effectiveness Testing of the Learning video}

The students learning outcomes after the product testing was acquired from pretest and posttest conducted in the product testing of learning video to 4 students of SDN Purwoyoso 02. The followings are the students learning outcomes in the product testing. 
Table 1. Learning Outcomes in Product Testing

\begin{tabular}{|c|c|c|c|}
\hline \multirow[t]{2}{*}{ No. } & \multirow[t]{2}{*}{ Remarks } & \multicolumn{2}{|c|}{$\begin{array}{l}\text { Classroom for } \\
\text { Product Testing }\end{array}$} \\
\hline & & Pretest & Posttest \\
\hline 1 & $\begin{array}{l}\text { Amount of } \\
\text { Students }\end{array}$ & 4 & 4 \\
\hline 2 & $\begin{array}{l}\text { Average } \\
\text { Grade Point }\end{array}$ & 65 & 77.5 \\
\hline 3 & $\begin{array}{l}\text { Worst Grade } \\
\text { Point }\end{array}$ & 55 & 65 \\
\hline 4 & $\begin{array}{l}\text { Best Grade } \\
\text { Point }\end{array}$ & 80 & 100 \\
\hline 5 & $\begin{array}{l}\text { Number of } \\
\text { Passed } \\
\text { Student }\end{array}$ & 3 & 4 \\
\hline 6 & $\begin{array}{l}\text { Number of } \\
\text { Unpassed } \\
\text { Students }\end{array}$ & 1 & 0 \\
\hline $\begin{array}{l}\text { Average } \\
\text { Collective } \\
\text { KKM (\%) }\end{array}$ & & $75 \%$ & $100 \%$ \\
\hline $\begin{array}{l}\text { Improveme } \\
\text { nt Rate (\%) }\end{array}$ & & $25 \%$ & \\
\hline
\end{tabular}

In the product testing conducted on 27 students of SDN Purwoyoso 01 Semarang I found the learning outcomes after taking pretest and posttest. The followings are the results of the product testing of the learning video.

Table 2. Learning Outcomes after Product Testing

\begin{tabular}{|c|c|c|c|}
\hline \multirow[t]{2}{*}{ No } & \multirow[t]{2}{*}{ Remarks } & \multicolumn{2}{|c|}{$\begin{array}{l}\text { Classroom for } \\
\text { Product Testing }\end{array}$} \\
\hline & & Pretest & Posttest \\
\hline 1 & $\begin{array}{l}\text { Amount of } \\
\text { Students }\end{array}$ & 27 & 27 \\
\hline 2 & $\begin{array}{l}\text { Average } \\
\text { Grade Point }\end{array}$ & 66.29 & 76.11 \\
\hline 3 & $\begin{array}{l}\text { Worst Grade } \\
\text { Point }\end{array}$ & 40 & 50 \\
\hline 4 & $\begin{array}{l}\text { Best Grade } \\
\text { Point }\end{array}$ & 95 & 95 \\
\hline 5 & $\begin{array}{l}\text { Number of } \\
\text { Passing } \\
\text { Student }\end{array}$ & 18 & 25 \\
\hline 6 & $\begin{array}{l}\text { Number of } \\
\text { Unpassed } \\
\text { Student }\end{array}$ & 9 & 2 \\
\hline $\begin{array}{l}\text { Average } \\
\text { Collective } \\
\text { KKM (\%) }\end{array}$ & & $66.67 \%$ & $92.59 \%$ \\
\hline $\begin{array}{c}\text { mprovement } \\
\text { Rate }(\%)\end{array}$ & & $25.92 \%$ & \\
\hline
\end{tabular}

$\mathrm{N}$-gain test was conducted during the product testing to find out the improvement of learning outcomes after using the learning video. $\mathrm{N}$-gain test shows that the collected data were fair. The followings are the results of $\mathrm{N}$ gain of product testing.

Table 3. N-gain of Product Testing

\begin{tabular}{cccc}
\hline $\begin{array}{c}\text { Average } \\
\text { Pretest } \\
\text { Score }\end{array}$ & $\begin{array}{c}\text { Average } \\
\text { Posttest } \\
\text { Score }\end{array}$ & \multicolumn{2}{c}{ Maximum } \\
Score & gain \\
\hline 67 & 80 & 100 & 0.39 \\
\hline
\end{tabular}

During the product testing, the students were also given pretest and posttest the results difference of which was calculated using $\mathrm{N}$-gain test. $\mathrm{N}$-gain test shows that the collected data were classified into "fair" category. The followings are the students $\mathrm{N}$-gain test results after the product testing.

Table 4. N-gain after Product Testing

\begin{tabular}{cccc}
\hline $\begin{array}{c}\text { Average } \\
\text { 'retest } \text { Score }\end{array}$ & $\begin{array}{c}\text { Average } \\
\text { Posttest } \\
\text { Score }\end{array}$ & \multicolumn{2}{c}{$\begin{array}{c}\text { Maximum N- } \\
\text { Score }\end{array}$} \\
gain \\
\hline 66.29 & 76.11 & 00 & 0.30 \\
\hline
\end{tabular}

After N-gain test had been conducted, pretest and posttest scores were calculated using SPSS 22-assisted t-test. T-test is used to assess the effectiveness of the applied learning video. The t-test used in this study was Paired Sample Test. On the output of SPSS v. 22-assisted paired sample test, I found that level of Sig (2tailed) was 0.000. Level of Sig (2-tailed) was $0.000<0.05$, thus, according to the foundation of decision-making in paired sample test, I can draw a conclusion that $\mathrm{Ho}$ was rejected and $\mathrm{Ha}$ was accepted, which means that Globalization lesson of Citizenship learning outcomes before and after using the learning video were significantly different.

Another study inspiring me to conduct research and development on learning video is the one conducted by I Made Karta, Sudaryono, and Herman Budiyono published in 2012 titled "Pengembangan Video Pembelajaran Menulis Puisi Baru Siswa Kelas V Sekolah Dasar" (Development of Learning Video on New Poem Writing for Grade V Students). The research shows that the learning video was applicable. It was shown by the assessment given by the media assessor certifying that the product was applicable to the learning of new poem writing. 
The individual testing regarding the usage of and the curiosity about the video shows percentage $96.3 \%$. The small group testing conducted on nine students shows that $94.4 \%$ the students like the video.

Another supporting study was the one conducted by I Gusti Lanang Agung Kartikan Putra, I Dewa Kd Tastra, IGN I Wy Suwatra published in 2014 titled "Pengembangan Media Video Pembelajaran dengan Model ADDIE pada Pembelajaran Bahasa Inggris di SDN Selat" (Development of Learning Video Using ADDIE Modeo for English Language Learning in SDN Selat). The study shows that in the media assessment, the media analyst gave percentage score $92.00 \%$ (excellent); in the assessment of learning design, the learning design analyst gave percentage score $85.00 \%$ (good), testing conducted by media analyst scored $88.00 \%$ (good), individual testing score $92.31 \%$ (excellent), small group testing scored $92.24 \%$ (excellent), and field testing scored $92.46 \%$ (excellent).

Another supporting study was the one conducted by Dian Maya Sari and Sahat Siagian published in 2013 titled "Pengembangan Media Video Pembelajaran Pangkas Rambut Lanjutan Berbasis Komputer Program Studi Tata Rias Rambut" (Development of Computer-Based Intermediate Hairdressing Learning Video for Department of Hairstyling). The study shows that the video was applicable according to the score given by assessor (95\%), the score of individual testing 90\%, small group testing scored $94.3 \%$, field testing on the aspect of quality of lesson materials showing average score $97.84 \%$, and the field testing for the aspect of technical/display quality showing average score $98.08 \%$. All the assessment scores were classified into "excellent" category.

The study conducted by Budi Prasetyo H.S., Rayandra Asyhar, Asrial published in 2011 titled "Pengembangan Video Pembelajaran Memperbanyak Tanaman Dengan Sambung Pucuk untuk Siswa SMK" (Development of Learning Video on Extending Plants through Grafting for Students of Vocational High School). The study shows that the scores given: by design analyst was $80 \%$ (good), by media analyst was $90 \%$ (excellent), by lesson materials analyst was $88 \%$ (excellent), by the students individually was $89 \%$ (excellent), by small group was 78\% (good), and by large group was $88 \%$ (excellent).
Alviya Agustina and Dian Novita in 2012 conducted a research titled "Pengembangan Media Pembelajaran Video untuk Melatih Kemampuan Memecahkan Masalah Pada Materi Larutan Asam Basa" (Development of Learning Video to Sharpen the Problem-Solving Skill for Acid-Base Solutions Lesson). From the study, I got the percentage of the feasibility of media form compatibility, i.e. $80.30 \%$, while the percentage of media quality was $81.25 \%$. Those percentages of the assessments were classified into "excellent" for durability and feasibility.

Another study was conducted by Ade Hadiati Nuzulina, Fauzi Bakri, and Esmar Budi published in 2015 titled "Pengembangan Video Pembelajaran Fisika pada Materi Fluida Statis $S M A$ " (Development of Physics Learning Video on Static Fluid Lesson in High School). The study shows that the scores given: by lesson materials analyst was $83 \%$, by media analyst was $84.1 \%$, by learning analyst was $72 \%$, and by physics teaching analyst was $90.1 \%$. The students' responses to the developed learning video shows the achievement percentage $86.1 \%$. The students had excellent interest in the video. From the tests conducted, they found that average pretest score was 61.13 and the average posttest score was $87.87 \%$.

Another relevant research was conducted by Fachrur Rozie published in 2013 titled "Pengembangan Media Video Pembelajaran Daur Air untuk Meningkatkan Proses dan Hasil Belajar IPA Siswa SD" (Development of the Learning Video on Water Cycle to Improve Natural Science Learning Process and Outcomes of Primary School Students). The study shows that feasibility study of the learning video shows the percentage $83.6 \%$ (feasible/good), lesson materials analyst gave score $92.5 \%$ (excellent).

The relevant study was conducted by Sushanta Kumar Roul published in 2014 titled "Language Development of the Preschool Children: The Effects of an Audio-Visual Intervention Program in Delhi". The study shows that there was comparison between posttest score in the classroom that did not use audio visual and the one in the classrooms that did.

Another study was conducted by Kristian Kiili, Keith Devlin, Arttu Perttula, Paulina Tuomi, and Antero Lindsted published in 2015 titled "Using Video Games to Combine Learning and Assessment in Mathematics 
Education". The study shows that the usage of the video game could give the students opportunity to understand the learning process. The video was attractive and effectively used in the learning process.

Another study was conducted by Maliheh Ghaedsharafi and Mohammad Sadegh Bagheri published in 2012 titled "Effect of Audiovisual, Audio, and Visual Presentations on EFL Learners Writing Skill". The study shows that using audiovisual media could improve the students' writing skill.

\section{Conclusion}

Based on the study above, I can draw a conclusion that the development of learning video on globalization was conducted through several phases, i.e.: a) analysis, which means to analyze the requirements to find out what media was needed and the collected data in the forms of questionnaire, interviews, observation, and documentation; b) design, the storyboard making; c) implementation which means the implementation of learning video making on globalization using Adobe Premiere Pro and Proshow Producer; d) testing which means validation conducted by analysts and revision team then conducting testing; e) maintenance which means that I did not conduct this phase because I merely tested it.

The developed learning video on globalization is feasible to apply. The feasibility of the video was shown by the scores given by lesson materials and media validators/analysts. The assessment conducted by lesson materials validator/analyst scored $82.14 \%$ which means "Good"/feasible. While The assessment conducted by media validator/analyst scored 85\% which means "Excellent".

Based on t-test, it got level of Sig (2tailed) 0.000. Level of Sig (2-tailed) was 0.000 $<0.05$. I can conclude that Ho was rejected, and Ha was accepted, which means that Globalization lesson of Citizenship learning outcomes before using the learning video has significant difference from the one after the usage.

\section{Gratitude}

I would like to thank my both parents for their supports and prayers, my Main Adviser Farid Ahmadi, S.Kom, M.Kom, Ph.D., Peer Reviewer I Harmanto, M.Pd., Peer Reviewer II Fitria Dwi Prasetyaningtyas, S.Pd.,M.Pd., the
English editor who wholeheartedly gave me advices.

\section{Reference}

Agustina, Alvia, dkk. 2012. "Pengembangan Media Pembelajaran Video untuk MelatihKemampuan Memecahkan Masalah Pada Materi Larutan Asam Basa".UnesaJournal of Chemical Education. Vol.1, No.1

Basil Youssef. 2012. "A Simulation Model for the Waterfall Software Development LifeCycle". International Journal of Engineering \& Technology.Vol.2 No.5

Depdiknas.2013. Peraturan Menteri Pendidikan Nasional nomor 22 tahun 2006tentang standar isi. Jakarta:Depdiknas

Ghaedsharafi, Maliheh, dkk. 2012. "Effect of Audivisual, Audio, and Visual Presentations on EFL Learners Writing Skill'.International Journal of English Linguistics. Vol.2, No.2

Karta, I Made, dkk. 2012. "Pengembangan Video Pembelajaran Menulis Puisi Baru Siswa Kelas V Sekolah Dasar".TeknoPedagogi Universitas Jambi. Vol.2, No.1

Kiili, Kristian, dkk. 2015. "Using Video Games To Combine Learning And Assessment In Mathematics Education".Tampere University of Technology. Volume 2, Issue 4

Nuzuluna, Ade Hadiati. 2015. "Pengembangan Video Pembelajaran Fisika pada Materi Fluida Statis SMA".Jurusan Fisikan FMIPA Universitas Negeri Jakarta. Volume IV

Prasetyo, Budi, dkk. 2011. "Pengembangan Video Pembelajaran Memperbanyak Tanaman Dengan Sambung Pucuk untuk Siswa SMK".Tekno-Pedagogi Universitas Jambi. Vol.1, No.1

Putra, I Gusti Lanang Agung Kartika, dkk. 2014. "Pengembangan Media Video Pembelajaran dengan Model ADDIE pada Pembelajaran Bahasa Inggris di SDN Selat". Jurnal Tenologi Pendidikan. Vol. 2, No. 1

Roul, Sushanta Kumar. 2014. "Language Development of the Preschool Children: The Effects of an Audio-Visual Intervention Program in Delhi".International Journal of Instruction. Vol.7, No.1 
Rozie, Fachrur. 2013. "Pengembangan Media Video Pembelajaran Daur Air untuk Meningkatkan Proses dan Hasil Belajar IPA Siswa SD".Jurnal Pendidikan Sains. Vol.1, No.4

Sari, Dian Maya, dkk. 2013. "Pengembangan Media Video Pembelajaran Pangkas
Rambut Lanjutan Berbasis Komputer Program Studi Tata Rias Rambut".Jurnal Teknologi Pendidikan. Vol.6, No.1

Sugiyono.2015. Metode Penelitian Pendidikan.

Bandung:Alfabeta 